\title{
THE STAKEHOLDER APPROACH TO IMPLEMENTATION OF TOURISM DEVELOPMENT STRATEGY
}

\section{STAKEHOLDER Př ÍSTUP K IMPLEMENTACI STRATEGIE ROZVOJE CESTOVNÍHO RUCHU}

\section{Mgr. Ing. MARTIN LUG்TICKÝ ${ }^{1}$}

\author{
ING. MICHAL NOVÁK ${ }^{2}$ \\ ING. PAVEL ĠVANDA ${ }^{1}$
}

\author{
${ }^{1}$ Katedra managemenut $\mid{ }^{I}$ Department of Management \\ ${ }^{2}$ Katedra exaktnich metod ${ }^{2}$ Department of Exact Methods \\ Fakulta managementu Faculty of Management \\ Vysoká ǵkola ekonomická v Praze University of Economics, Prague \\ $\square$ Jaroğvvská 1117/II, 37701 JindṠich Tv Hradec, Czech Republic \\ E-mail: lusticky@fm.vse.cz
}

\begin{abstract}
Annotation
This paper is focused on planning of tourism development with an emphasis on the issue of regional stakeholdersô involvement in the implementation phase of regional strategy. It refers to the importance of collaboration between regional destination management organization and regional stakeholders for successful development of tourism. The paper suggests a method for stakeholder analysis which is considered as a starting point of the collaboration process. The method is based on an analysis of three attributes which characterize the importance of stakeholders for tourism development and their attitude to the implementation process of the strategic priorities. The stakeholder analysis is realized in the South Bohemia Region, which is selected as a testing area for verification of suggested methodology.
\end{abstract}

Key words

tourism, planning, stakeholders, analysis

\section{Anotace}

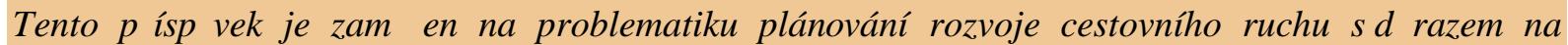
zapojení regionálních stakeholders do implementa! ní fáze regionální strategie. ZdTrazŔkje význam spolupráce mezi krajskou organizací destina! ního managementu a regionálními stakeholders pro úsplöný rozvoj cestovního ruchu. PŚsp円ek navrhuje metodiku analýzy stakeholders, která je povaǵbvána za východisko pro nastartování procesu spolupráce. Metodika je zaloǵena na zkoumání tŚi atribut T, které charakterizují význam stakeholders pro rozvoj cestovního ruchu a také jejich postoj k procesu implementace strategických priorit. Analýza stakeholders je realizována v Jihol eském kraji, který je zvolen jako testovací oblast pro ovhśení navróené metodiky.

\section{Klị́ ová slova}

cestovní ruch, plánování, stakeholders, analýza

JEL classification: $R 58$ 


\section{Introduction}

Tourism contributes to both regional and local economy stability, especially due to its positive multiplier effect. Therefore, national and regional governments make an effort to strengthen competitiveness within their tourism policy. Although strategic planning process cannot guarantee the success of tourism destinations, it is one of the widely recognized factors of competitiveness (Dwyer \& Kim, 2003, Ritchie \& Crouch, 2003). It contributes to the sustainable and efficient utilization of resources in compliance with the internal and external conditions (Hall, 2008). As Pechlaner \& Saurwein (2002) stated, considerable attention is devoted to strategic planning. The process of implementation is not examined in such a detailed way. Nevertheless, the implementation phase is crucial for the success of a strategy as a whole; without it the entire process loses its purpose (Poister \& Streib, 1999).

The same situation happens in the sphere of implementation of the strategies for tourism development. In the development strategies, only insufficient space is devoted to the phase of implementation, and the conditions for its realization are often insufficiently prepared (Luġický, 2011, Luġický \& Kincl, 2012). This is also reflected in practice where co-operation between public administration and regional stakeholders often fails or it exists only on a formal basis (Luġický, Zaunmüllerová \& Havlová, 2013). Nevertheless, the importance of the involvement of regional stakeholders in the strategy implementation process is emphasized by a number of authors (Ritchie \& Crouch, 2003, Hall, 2008). Some authors consider this co-operation as an essential prerequisite to achieving a sustainable competitive advantage (Byrd, Cárdenas \& Greenwood, 2008).

\section{Aim and methodology}

Even though tourism management involving regional stakeholders is difficult, the destination management organizations (DMOs) should not resign their coordination and realization role, as they are the bearer of the tourism policy. To fulfill this task it is necessary to identify regional stakeholders, characterize them and recognize their attitudes. This process is often a critical point that affects the entire process of planning and implementing strategies (Aas, Ladkin \& Fletcher, 2005).

For that reason, the main aim of this paper is to propose a process of stakeholder analysis based on the Stakeholder Circle method that is modified towards conditions of tourism. It identifies key stakeholders, prioritizes them and assesses their opinion on co-operation with destination management organization within the implementation process of regional tourism development strategy. The paper verifies the procedure within the conditions of the South Bohemian Region (Czech Republic).

There are many definitions of stakeholders in the literature. They oscillate from a broad interpretation that includes all subjects somehow connected with the organization to relatively narrow interpretations tailored for the purposes of the research (Sheenan, 2006). Freemanô classic definition considers stakeholder as ñany group or individual who can affect or is affected by the achievement of the organization's objectivesò (Freeman, 1984: 46). This research considers stakeholders to be organizations that operate in regions influenced by the strategy, and participate in the fulfilment of strategic priorities, or are substantially affected by these priorities. It is a modification of above mentioned Freemanô definition and definition of Presenza, Sheenan \& Ritchie, who define stakeholders as ñny entity that is influenced by, or that may influence, the achievement of the destination management activitiesò (Presenza, Sheenan \& Ritchie, 2005: 9).

The analysis of stakeholders is one of the methods of strategic analysis. In general, it is possible to define this analysis as a process that identifies entities that can be influenced by the activities of particular organization, examines and groups together these entities according to their importance for the organization (Reed et al., 2009). This paper presents a specific method of stakeholder analysis that is based on the Stakeholder Circle method and modified for the conditions of strategic analysis in tourism. In compliance with the approach of Mitchell, Agle \& Wood (1997), Bryson (2004), Sheenan 
(2006), and L̦ástek (2010), the stakeholder analysis uses this set of attributes for basic characterization of the stakeholder groups:

- Power $(\mathrm{P})$ : the attribute identifies such stakeholder group which is deciding for achievement of the strategic priority;

- Ability to co-operate (A): the attribute identifies such stakeholder group which is non-conflict and capable to co-operate in achievement of the strategic priority;

- Urgency (U): the attribute identifies such stakeholder group which is frequently involved in achievement of the strategic priority.

Just as the Stakeholder Circle method, the stakeholder analysis allows calculating the Stakeholder Index. This index allows ranking the stakeholder groups by importance based on selected attributes. Thus, it indicates those regional stakeholders the destination management organization should focus on when implementing the strategy. The Stakeholder Index is calculated by the following formula:

$\mathrm{SI}=\sum(\mathrm{P}, \mathrm{A}, \mathrm{U})$

The required data for stakeholder analysis are obtained by the means of semi-structured interviews with members of top management of the regional destination management organization (the South Bohemia Tourism Authority). Buhalis (2000), Presenza, Sheenan \& Ritchie (2005) emphasize the importance of these organizations in tourism management and in the implementation of the strategy in administrative or local government regions. They consider them as the main initiators of tourism development in the destination and as the coordinators of co-operation with regional stakeholders.

The aim of the survey is to characterize the stakeholders groups assembled according to the selected attributes and identify key groups according to the value of the Stakeholder Index. The survey uses standard five-point Likert scale for expression of the value of particular attribute. Respondents indicate their level of agreement with pre-defined statements on the following scale: (5) strongly agree; (4) agree; (3) neutral; (2) disagree; (1) strongly disagree. The statements are as follows:

- Power: This group of stakeholders is deciding for achievement of the strategic priority;

- Ability to co-operate: This group of stakeholders is non-conflict and capable to co-operate in achievement of the strategic priority;

- Urgency: This group of stakeholders is frequently involved in achievement of the strategic priority.

The next phase of the research is focused on particular representatives of the key stakeholder groups. Its aim is to describe their opinion on co-operation with the regional destination management organization. For this reason the previous attributes are modified to the following set:

- Attitude: This attribute identifies stakeholders which have positive approach to co-operation in achievement of the strategic priority;

- Interest: This attribute identifies stakeholders which have a spirit of initiative and actively cooperate in achievement of the strategic priority;

- Capability: This attribute identifies stakeholders which have sufficient capacity of the resources and which are able to use them for achievement of the strategic priority.

This phase is realized by an on-line survey. The survey uses a combination of five-point Likert scale and open questions to be able to ascertain the views of regional stakeholders on co-operation with the destination management organization within implementation of the strategic priorities of current tourism development strategy.

\section{Results and discussion}

Table 1 summarizes results of the first phase of our research. Stakeholder groups are compiled based on an approach of Byrd, Cárdenas \& Greenwood (2008), Presenza, Sheenan \& Ritchie (2005), and Buhalis (2000). The table shows values of the attributes in a pre-defined Likert scale. The attributes are stated for all strategic priorities (SP). Stakeholder groups are sorted in the order of their importance according to the value of the Stakeholder Index (SI). 
Tab. 1: The Attributes of Regional Stakeholders

\begin{tabular}{|l|c|c|c|c|c|c|c|c|c|c|c|c|c|}
\hline \multirow{2}{*}{ Stakeholder Groups } & \multicolumn{3}{|c|}{ SP1 } & \multicolumn{3}{|c|}{ SP2 } & \multicolumn{3}{|c|}{ SP3 } & \multicolumn{3}{|c|}{ SP4 } & \multirow{2}{*}{ SI } \\
\cline { 2 - 16 } & P & A & U & P & A & U & P & A & U & P & A & U & \\
\hline District towns & 5 & 5 & 5 & 5 & 5 & 5 & 4 & 5 & 5 & 4 & 5 & 5 & $\mathbf{5 8}$ \\
\hline Local DMOs & 5 & 5 & 5 & 5 & 5 & 5 & 4 & 5 & 3 & 5 & 5 & 5 & $\mathbf{5 7}$ \\
\hline Regional development agencies & 5 & 4 & 4 & 3 & 4 & 3 & 3 & 2 & 2 & 5 & 4 & 4 & $\mathbf{4 3}$ \\
\hline Regional tourism organizations & 5 & 3 & 3 & 3 & 3 & 2 & 3 & 2 & 2 & 5 & 3 & 3 & $\mathbf{3 7}$ \\
\hline Universities & 1 & 1 & 1 & 3 & 4 & 3 & 1 & 3 & 1 & 1 & 2 & 2 & $\mathbf{2 3}$ \\
\hline
\end{tabular}

The strategy for tourism development in the South Bohemia Region is divided into 4 main strategic priorities: (1) Supporting the Development and Improvement of Tourism Infrastructure (SP1); (2) Promoting Education and Human Resource Development in Tourism (SP2); (3) Monitoring and Evaluating Legislation (SP3); and (4) Support for the Creation of Tourism Products (SP4).

The most important stakeholder groups are district towns in the South Bohemia Region and local destination management organizations. These groups are crucial for implementation of all strategic priorities. Their support is very important for successful tourism development and they help the regional DMO to play its coordination and realization role. Co-operation between these stakeholder groups is considered very intensive based on the strong long-term ties and regular meetings. It is positive that both of the groups are perceived as non-conflict and they actively co-operate with the DMO in achievement of the strategic priorities.

Regional development agencies and regional tourism organizations are considered to be secondary stakeholders. They are very important for achievement of two strategic priorities (SP1, SP4) which are closely connected with tourism supply and subsequent infrastructure. Their role in implementation of others priorities is not so intensive. Although the co-operation with many regional tourism organizations is extremely difficult, it would be necessary to involve them more intensively in the implementation process, and to formalize and stimulate the mutual collaboration between them and the regional DMO. Local universities are important stakeholders for realization of the third strategic priority which is focused on human resource development. Nevertheless, the co-operation takes place rather abruptly in the context of specific projects.

When realizing the strategic priorities, most stakeholders collaborate with the regional destination management organization within the framework of joint marketing, participating in tourism fairs, joint actions promoting the development of tourism, or creating promotional products. They can also provide valuable information on the development of tourism and visitor satisfaction. In certain cases they co-ordinate activities of private sector organizations. They also participate in joint projects supporting the tourism infrastructure as administrators of grant programs or as investors.

The next phase of the research is designed to evaluate the views of regional stakeholders on cooperation with the destination management organization within the implementation of strategic priorities. The survey was conducted with representatives of key regional stakeholders:

- municipal authorities of district towns: Leské Bud円ovice, Strakonice, Prachatice, JindŚchTv Hradec, Tábor

- local destination management organizations: DMO L̦eský Krumlov, DMO Písek, DMO Lipensko

In the city of Leský Krumlov and Písek the survey involves only the representatives of local destination management organizations because they have a direct link with the local government (municipal authorities).

Figure 1 illustrates the results of the survey. The figure is divided into four quadrants which represent four strategic priorities of the tourism development strategy in the South Bohemia Region. Based on the results of the survey, the individual stakeholders are characterized by these three attributes: 
- Attitude: This attribute is depicted by a distance from left axis of the quadrant;

- Interest: This attribute is depicted by a distance from the center of the circle;

- Capability: This attribute is depicted by an area of a mark which indicates the individual stakeholder.

- municipal authorities of district towns: square number 1 ï 5

- local destination management organizations: circle number 1 ï 3

\section{Fig. 1: Analysis of the key stakeholders}
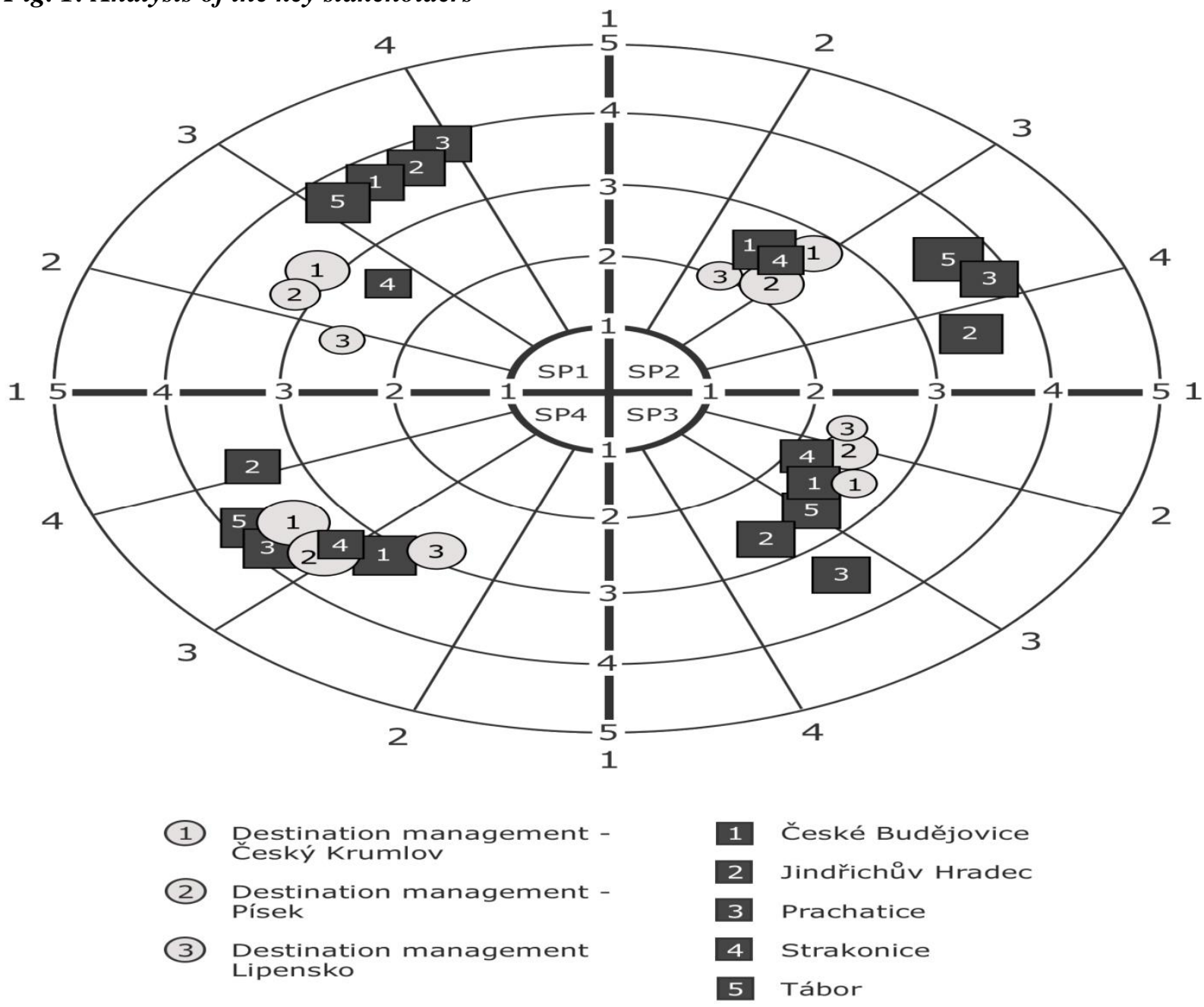

Source: own elaboration

Figure 1 illustrates a situation in the sphere of co-operation between key regional stakeholders and the regional DMO. In general, more intensive co-operation occurs with municipal authorities than with local destination management organizations. Municipal authorities also have more favorable attitude to co-operation; local DMOs are more critical. Nevertheless, all stakeholders are involved to implementation of the strategic priorities and their attitude to co-operation is more positive than negative. The most positive results of all three attributes stakeholders indicate in the case of the strategic priority 4 ñSupport for the Creation of Tourism Productsò. Thus the strategic priority 4 seems to be based on basic characteristics of a collaborative planning that describe Medeiros de Araujo and Bramwell (1999). The strategic priorities 1 and 2 show acceptable results too. Stakeholders appreciate the activities of the South Bohemia Tourism Authority but their interest is not so intensive. It may be caused by a lack of financial resources (SP1) and time (SP2). Orientation of the third strategic priority to the sphere of legislation is very specific. This fact reflects the level of interest and attitude of the stakeholders which is rather low. The only exception is the city of Prachatice which adopts a proactive stance on achievement of this strategic priority. 
From the point of view of particular stakeholders, the cities of JindŚchTv Hradec, Prachatice and Tábor declare the highest level of interest in co-operation with the regional DMO and simultaneously these cities belong among the most satisfied stakeholders. They also proclaim sufficient capacity of human resources, knowledge and time and readiness to use them for achievement of the strategic priorities. The representatives of Strakonice and L eské BudDovice are more reserved in their evaluation. Attention of the regional DMO should be paid primarily to municipal office of Leské Bud Dovice which is the capital city of the region and declares high capacity of the resources needed for achievement of the strategic priorities. Very similar situation comes in the case of two local destination management organizations directly connected with local government. In spite of rather positive attitude to implementation of the strategic priorities 1 and 4, these organizations are not still fully integrated into implementation of the regional strategy. The view of the DMO Lipensko to collaboration with the regional DMO is different in many cases. This local DMO has such organization structure which is not directly connected with local government and the Lipno Lake is a specific tourism destination different from other cities in the South Bohemia Region. In any case, this is not a good sign for the regional DMO. It would be appropriate to take steps to remedy, particularly with regard to tourism potential of the Lipno Lake and its surroundings.

\section{Conclusion}

It is possible to say that the first phase of the research is successful. The proposed procedure of stakeholder analysis is usable in practice. It allows characterizing the stakeholder groups within the framework of defined attributes, ranking the stakeholder groups by their importance and describing relationship between the regional DMO and key stakeholders within implementation of the strategic priorities.

The research indicates that all regional stakeholders are involved in the implementation of the strategic priorities, though not equally. The regional DMO is in a closer contact with the representatives of municipal authorities ï primarily the cities of JindŚchTv Hradec, Prachatice and Tábor. The local destination management organizations have not so intense relationship with the regional DMO which is reflected in their attitude and interest in co-operation. The Destination management Lipensko stands on the edge of collaborative planning process and so the regional DMO must make an effort to improve the relationships with this organization.

The stakeholder analysis represents the first step of a continual improvement process of tourism collaborative planning. It allows finding several opportunities for improvement in all strategic priorities. These opportunities will be an object of consequent research. It will detect and analyse the most important failings of co-operation and try to propose managerial arrangements for their reduction in such a way to be beneficial for both parties and to achieve that the regional stakeholders could actively participate in all strategic priorities. The research will be extended to other regions of the Czech Republic or to selected foreign destinations to strengthen the possibility of finding transferable good practices for an improvement of the strategic planning process with involvement of regional stakeholders.

\section{References}

[1] AAS, CH., LADKIN, A., FLETCHER, J., (2005). Stakeholder Collaboration and Heritage Management. Annals of Tourism Research, vol. 32, iss. 1, pp. 28-48. ISSN 0160-7383. DOI 10.1016/j.annals.2004.04.005.

[2] BRYSON, J. M., (2004). What to do when Stakeholders matter: Stakeholder Identification and Analysis Techniques. Public Management Review, vol. 6, iss. 1, pp. 21-53. ISSN 1471-9037. DOI 10.1080/14719030410001675722.

[3] BUHALIS, D., (2000). Marketing the Competitive Destination of the Future. Tourism Management, vol. 21, iss. 1, pp. 97 ï 116. ISSN 0261-5177. 
[4] BYRD, E. T., CARDÉNAS, D. A., GREENWOOD, J. B., (2008). Factors of stakeholder understanding of tourism: The case of Eastern North Carolina. Tourism and Hospitality Research, vol. 8, iss. 3, pp. 192-204. ISSN 1467-3584. DOI 10.1057/thr.2008.21.

[5] ĹÁSTEK, O., (2010). Vyuğití stakeholderského pŚstupu pŚ strategické analýze podniku. Brno: Masarykova univerzita. ISBN 978-80-210-5411-0.

[6] DWYER, L., KIM, C., (2003). Destination Competitiveness: Determinants and Indicators. Current Issues in Tourism, vol. 6, iss. 5, pp. 369-414. ISSN 1368-3500. DOI 10.1080/13683500308667962.

[7] FREEMAN, R. E., (1984). Strategic Management: A stakeholder approach. Boston: Pitman. ISBN 9780521151740.

[8] Hall, C. M., (2008). Tourism Planning: Policies, Processes and Relationships. Harlow: Prentice Hall. ISBN 978-0-13-204652-7.

[9] LUǴTICKÝ, M., (2011). Benchmarking as a Quality Enhancement Method of Regional Planning in Tourism. Journal of Global Management, vol. 2, iss. 1. pp. 1-11. ISSN 977-2229-919X.

[10] LUĠTICKÝ, M., KINCL, T., (2012). Tourism Destination Benchmarking: Evaluation and Selection of the Benchmarking Partners. Journal of Competitiveness, vol. 4, iss. 1, pp. 99-116. ISSN 1804-171X. DOI 10.7441/joc.2012.01.08.

[11] LUǴTICKÝ, M., ZAUNMÜLlEROVÁ, P., HAVlOVÁ, L., (2013). Stakeholder Analysis in Selected Tourism Destinations. In International Academic Conference on Social Sciences. Conference Proceedings. Istanbul: IACSS. pp. 292-297. ISBN 978-9941-05712-0.

[12] MEDEIROS DE ARAUJO, L., BRAMWELL, B., (1999). Stakeholder Assessment and Collaborative Tourism Planning: The Case of Brazilôs Costa Dourada Project. Journal of Sustainable Tourism, vol. 7, iss. 3-4, pp. 356-378. ISSN 0966-9582. DOI 10.1080/09669589908667344.

[13] MITCHELL, R. K., AGLE, B. R., WOOD, D. J., (1997). Toward a Theory of Stakeholder Identification and Salience: Defining the Principle of Who and What Really Counts. The Academy of Management Review, vol. 22, iss. 4, pp. 853-886. ISSN 0363-7425.

[14] PECHLANER, H., SAUERWEIN, E., (2002). Strategy implementation in the Alpine tourism industry. International Journal of Contemporary Hospitality Management, vol. 14, iss. 4, pp. 157-168. ISSN 09596119. DOI 10.1108/09596110210427003.

[15] POISTER T. H., STREIB, G., (1999). Strategic Management in the Public Sector: Concepts, Models, and Processes. Public Productivity \& Management Review, vol. 22, iss. 3, pp. 308-325. ISSN 1044-8039.

[16] PRESENZA, A., SHEENAN, L., RITCHIE, J. R. B., (2005). Towards a model of the roles and activities of destination management organizations. Journal of Hospitality, Tourism and Leisure Science, vol. 3, iss. 1, pp. 1-16. ISSN 1473-8376.

[17] REED, M. S. et al., (2009). Whoôs in and why? A typology of stakeholder analysis methods for natural resource management. Journal of Environmental Management, vol. 90, iss. 5, pp. 1933-1949. ISSN 10958630. DOI 10.1016/j.jenvman.2009.01.001.

[18] RITCHIE, J. R. B., CROUCH, G. I., (2003). The competitive destination: a sustainable tourism perspective. Wallingford: CABI Publishing. ISBN 978-0-85199-664-6.

[19] SHEENAN, L. R., (2006). Destination Management Organizations: A Stakeholder Perspective [online]. Ph.D. Thesis. Calgary: Haskayne School of Business, [cit. 2014-04-07]. Available at: <http://search.proquest.com/docview/304899195>. 